ШАЛЫГИНА Наталья Валентиновна - кандидат исторических наук, старший научный сотрудник Института этнологии и антропологии им. Н.Н. Миклухо-Маклая РАН (119334, Россия, г. Москва, Ленинский np-кm, 32a; etgender@mail.ru)

\title{
ПУЭРТО-РИКО: КРИЗИС ЭТНИЧЕСКОЙ ИДЕНТИФИКАЦИИ
}

Аннотация. Статья посвящена проблемам становления этнической идентификации Пуэрто-Рико островного государства Карибского бассейна, имеющего статус свободно присоединившегося к США государства. Более чем вековая история развития отношений Пуэрто-Рико и США показывает не только реализацию политики американского «прогрессорства» в системе глобального мира, но и то, насколько драматичным может быть стремление небольшой страны обрести собственный суверенитет, находясь в орбите геополитических интересов США.

Ключевые слова: суверенитет, независимость, Пуэрто-Рико, США, историко-культурная общность, этническая идентификация, иммиграция, структурная ассимиляция

Сатус острова Карибского бассейна Пуэрто-Рико как свободно присоединившегося к США государства сегодня все чаще оказывается в центре мировой социально-политической аналитики. Исторический прецедент 1898 г., когда в результате окончания испано-американской войны жители острова формально перестали считаться частью единого пространства латиноамериканской историко-культурной общности и перешли во владение США, до сих пор провоцирует неоднозначные интерпретации со стороны экспертного сообщества историков, политологов и культурных антропологов.

По сути, этот относительно небольшой остров в Карибском бассейне стал североамериканской колонией, однако его формальный статус по отношению к Соединенным Штатам долгое время оставался весьма неопределенным. Причин тому немало, но главной все же, по-видимому, следует считать конъюнктурную политику самих США в этом регионе. Еще в начале XIX в., используя благоприятный момент в войне Испании с Англией за владение колониями в Карибском море, Соединенные Штаты сочли весьма своевременным и возможным для себя вмешаться в эту ситуацию с решительным протестом против нарушения статус-кво Пуэрто-Рико и Кубы [Nazario 1961: 32]. Такая позиция была продолжением политики США в отношении испанских колоний, занимавших важное стратегическое положение на американском континенте. Американское правительство уже тогда рассматривало Пуэрто-Рико и Кубу как необходимое дополнение к своим территориям и выжидало лишь момента для их захвата. Когда же такой момент настал, и Испания, согласно Парижскому мирному договору (декабрь 1898 г.), уступила Кубу и Пуэрто-Рико США [Москаленко 1974: 45], функции государства«правозащитника» не позволили Соединенным Штатам прямо объявить «освобожденные» острова своими собственными колониями. Началось то, что сегодня можно было бы назвать скрытой, завуалированной оккупацией приобретенных территорий. Военное командование США распустило пуэрториканское правительство и отменило многие местные законы. На острове были введены федеральные законы США, а экономика оказалась подчиненной нуждам североамериканского рынка.

На сегодняшний день Пуэрто-Рико имеет статус неинкорпорированной организованной территории. Это означает, что остров находится под управлением США, верховная власть в Пуэрто-Рико принадлежит конгрессу США, 
но действие американской конституции на острове ограничено ${ }^{1}$. Похожим образом, заметим, США выстроили отношения еще с несколькими островными государствами (Гуам, Американские Виргинские Острова и др.), которые сегодня имеют статус владений. Жители всех этих территорий (за исключением Американского Самоа) - граждане США. Пуэрториканцы стали гражданами США в 1917 г., а в 1952 г. остров получил юридический статус содружества (commonwealth), решение о котором было принято на общенациональном референдуме Пуэрто-Рико. Этот статус достаточно размыт, но подразумевает право на самоуправление, которое не может быть отменено в одностороннем порядке правительством США.

По мнению американских политологов, статус свободно присоединившегося государства является оптимальным вариантом построения отношений между развитыми капиталистическими странами и теми странами, которые еще относительно недавно назывались развивающимися и которые, как принято считать в западном мире, нуждались в «прогрессорстве». Вопрос о суверенитете этих стран, как правило, замалчивался или объявлялся второстепенным. Судьба Пуэрто-Рико в этом контексте нередко признается «эталоном» встраивания развивающегося государства в систему так называемого глобального мира. Так ли обстоит дело на самом деле? Можно ли признать путь, которым идет островное государство Пуэрто-Рико, «рецептом для всех»? И не является ли утрата этнокультурной специфики народов несоразмерной платой за евроатлантическое «прогрессорство»? Опыт Пуэрто-Рико показывает, что стремление островитян к воссоединению с США чревато потерями, значение которых для будущего развития этноса трудно переоценить.

Одним из наиболее очевидных показателей негативных изменений, связанных с особым статусом острова, стал отток его населения на материковую часть США. Уже к 1920 г. пуэрториканское население материка составляло 11,8 тыс. чел. [Annual Report... 1936: 12], и это вдвое больше по сравнению с 1910 г., когда иммиграция с острова стала принимать массовый характер. Основная причина увеличения иммиграционных потоков - разорение крестьянства и ухудшение экономического положения основной массы населения острова из-за захвата североамериканскими монополиями земель для разведения сахарного тростника и отмены свободы внешней торговли, которой остров пользовался до 1898 г. К началу последнего десятилетия XX в. число пуэрториканцев в США насчитывало уже почти 2,7 млн чел. ${ }^{2}$

Но расчет островитян на обретение земного рая на материке не оправдался. И причиной тому стал в первую очередь особый характер пуэрториканской иммиграции. С одной стороны, пуэрториканцы уже были гражданами США, когда пошла самая массовая волна их эмиграции на материк. В истории США это случай беспрецедентный. Все другие волны иноэтничной иммиграции сталкивались здесь с проблемами правовой легализации со множеством вытекающих отсюда последствий. Для огромного числа переселенцев, вновь прибывающих в Соединенные Штаты, как правило, первичный период адаптационного процесса оказывался и оказывается сопряженным с усилиями, направленными на получение легального статуса, в силу чего непосредственный контакт с новой культурой приобретал отягощенный неизбежными формальностями характер.

С другой стороны, островитяне еще не стали настоящими американцами. Наличие статуса гражданина США сразу же после переезда на материк ввергало

\footnotetext{
1 https://regnum.ru/news/1936299.html

2 U.S. Bureau of the Census. Spanish language and other persons of Spanish surname. 1970 - tabl. D-4; 1980 - tabl. D-3; 1990 - tabl. D-1.
} 
пуэрториканцев в водоворот чуждых их культуре прав и обязанностей, понять и принять которые при отсутствии целенаправленных установок и в состоянии эйфории было непросто. К тому же возможность беспрепятственно перемещаться на остров и обратно создавала такие условия, при которых переселенцы всегда могли вернуться на родину, если жизнь на материке оказывалась для них слишком сложной. В результате пуэрториканская эмиграция к концу этого периода стала носить явно выраженный челночный характер, что, по-видимому, стало одним из важнейших факторов трансформации традиционных ценностей самих пуэрториканцев [Lockett 1964: 76].

Таким образом, массовая миграция пуэрториканцев на материк, носящая благодаря особому статусу острова челночный характер, не способствовала полноценной структурной ассимиляции островитян в США. При этом их тяжелое и болезненное вхождение в североамериканскую социально-экономическую структуру сопровождалось не только разочарованиями и потерей веры в «американскую мечту», но и неизбежным в таких ситуациях обращением к собственной культуре как поддержке и убежищу [Шалыгина 2007: 145]. Уже в 1930-1945 гг. начался спад эмиграции с острова и формирование идеи независимости от США. Так, в мае 1930 г. впервые была озвучена задача безотлагательного упразднения власти североамериканского капитала на острове, созыва конституционного собрания, которое, как предполагалось, создаст правительство независимой республики [Vazques Calzanda 1963: 75]. Президент националистической партии Педро Альбиус Кампос развернул активную антиколониальную пропаганду. Идея независимости получила небывалое распространение в самых различных социальных слоях пуэрто-риканского общества. Впервые ни один крупный политический лидер не решался открыто осуждать или оспаривать ее. Напротив, все существующие в Пуэрто-Рико политические партии вынуждены были включить в свои программы положение о будущей независимости острова.

Страна была охвачена патриотическим порывом. «Пуэрто-Рико, - говорил Кампос в одном из выступлений, - представляет собой картину крушения высших человеческих ценностей: чести, патриотизма, самопожертвования. Империализм янки привел нас в моральном плане к презрению самих себя, в материальном смысле собственники превратили нас в рабов, а из рабов - в нищих, приговоренных к смерти. Поэтому единственно возможным решением является национализм, так как он возрождает в каждом из нас сознание свободного человека, для которого человеческое достоинство бесценно» [Corretier 1965: 12].

Однако, несмотря на очевидный подъем патриотизма, в тот период верх снова и явно одержала тенденция к всемерному сближению с США, пусть даже путем отказа от национального суверенитета Пуэрто-Рико. Бурные дискуссии относительно американских ценностей в целом оказались настолько популярными в политических кругах, что, по сути, оттеснили на второй план саму проблему борьбы за независимость. Длительный процесс американизации острова приносил свои плоды, и исторически сложившаяся культурная самоидентификация островитян постепенно размывалась, все больше и очевиднее насыщаясь иными ценностями, отличными от традиционных. Вступление США во Вторую мировую войну в начале 1940-х гг. несколько ослабило влияние, которое пуэрториканцы испытывали со стороны своего северного соседа, но ненадолго. «Идейная платформа» была уже прочно заложена, а победоносные фанфары американцев в 1945 г. только усилили эффект ее воздействия на сознание островитян.

Первые послевоенные годы ознаменовались стремлением населения ПуэртоРико не только разделить с державой-победительницей лавры военного успеха, 
но и приобщиться к впечатляющим перспективам беспрецедентного в истории США экономического бума. Этот период в истории острова как никакой другой, наверное, можно было бы сравнить с массовой эйфорией, наполненной иллюзиями и надеждами.

Ярчайшим проявлением стремления к слиянию с США вновь стало увеличение эмиграционных потоков с острова. Пуэрториканцы, как и многие другие этнические группы послевоенного времени, воспринимали эмиграцию в США как решение всех проблем, гарантию выживания для себя, своих детей и близких [Mass 1977: 112]. Позитивный накал эмоций на острове тех лет был настолько велик, а будущее самих США казалось настолько радужным, что послевоенную эмиграцию пуэрториканцев, наверное, с тем же успехом можно назвать культурной. Идеалы и ценности американцев приобрели для островитян самодостаточное значение, ассоциативную бесспорность победы одного конкретного образа жизни над всеми другими. Иммиграционная волна «пуэрториканских американцев», желающих воспользоваться своими гражданскими правами, чтобы жить и работать на материке, буквально захлестнула крупные города США, нарастая с каждым днем.

Антиамериканские настроения на самом острове хотя и продолжали звучать, но к этому голосу уже мало кто прислушивался. Тем более что со стороны США делалось все возможное, чтобы заглушить его. В октябре 1950 г. националисты попытались возглавить восстание против американцев. Поводом для него послужило требование Пентагона увеличить призыв пуэрто-риканской молодежи в армию США для ведения войны в Корее. В округе Хайюя восставшие захватили власть и провозгласили независимую республику Пуэрто-Рико. Однако восстание было подавлено. Правительство США не только жестоко расправилось с патриотами, но и решительно отвергло предложенные в 1930-х гг. конгрессу проекты о предоставлении острову независимости. Казалось, все шло к тому, что пуэрториканцы сменят свою национально-культурную самоидентификацию и вольются в рациональное сообщество североамериканских штатов [Torres, Velazquez 1998: 88].

Дальнейшие события показали, что идея суверенитета и независимости от США все-таки не исчезла из сознания островитян, а, наоборот, постепенно начала обретать институциональные формы. Наиболее заметной организацией, выступившей еще в середине XX в. против господства США на Пуэрто-Рико, стала Пуэрториканская социалистическая партия, просуществовавшая более 35 лет (1959-1993 гг.). Объединив вокруг себя множество других политических партий острова, борющихся за независимость страны от США (Партия независимости Пуэрто-Рико, Коммунистическая партия Пуэрто-Рико и др.), ПСП, по сути, организовала левый фронт, используя все пути борьбы - от партизанского движения до новейших для того времени электоральных технологий, но отрицая при этом крайности национализма. В последующие годы в левый фронт вошли такие партии, как Университетская организация за независимость, Социалистическое рабочее движение (1982 г.), Остосианское движение за независимость (2004 г.), «Движение к социализму» (2008 г.) и др.

Однако программы левого движения, несмотря на их многочисленность, как оказалось, не отвечали истинным чаяниям островитян. Идея независимости от США, которая периодически выносилась на всенародный референдум в Пуэрто-Рико (1967, 1993, 1998, 2012, 2017 гг.), не была поддержана большинством пуэрториканцев. По Конституции США населению острова предлагались 3 варианта развития событий: сохранение нынешнего статуса, обретение независимости или вхождение в состав Соединенных Штатов на правах штата (соответствующий вердикт был вынесен специальной президентской комис- 
сией по определению будущего Пуэрто-Рико, учрежденной Биллом Клинтоном в 2000 г.). Первые три референдума показали, насколько трудным является для островитян вопрос самоопределения - процентное соотношение голосов не отвечало правилам проведения референдума и не решало проблемы. И лишь референдум 2012 г. показал, что 61,15\% голосов островитяне отдали за то, чтобы стать полноценным штатом США. В 2017 г. результаты очередного всенародного голосования показали, что эту идею поддерживают 97,18\% граждан ПуэртоРико ${ }^{1}$. Таким образом, более чем вековой спор о независимости Пуэрто-Рико можно считать законченным. Но решает ли вхождение острова в состав США все накопившиеся за это время этнокультурные проблемы? Не станет ли этнополитический тренд последних десятилетий, называемый «миской салата» и откровенно противостоящий глобалистским проектам, тем неодолимым препятствием, которое все-таки не позволит пуэрториканцам США стать «полноценными» американцами? Похоже, что ответ на этот вопрос уже не за горами.

\section{Список литературы.}

Москаленко А.П. 1974. Пуэрто-Рико и США. М.: Наука. 207 с.

Шалыгина Н.В. 2007. Кризис семьи в эмиграции. США. Пуэрториканская модель. М.: Изд-во ИЭА РАН. 250 с.

Annual Report of the Commissioner of Labor Submitted to the Governor of Puerto Rico. 1936. San Juan, P.R.: Bureau of Supplies, Print. and Transportation.

Corretier J.A. 1965. Albizu Campos and the Ponce Massacre. San Juan: World View Publishers. 25 p. URL: https://www.marxists.org/history/erol/ncm-8/prsl-ponce.pdf. Lockett E.B. 1964. The Puerto Rican Problem. N.Y.: Exposition Press. 196 p.

Mass B. 1977. Puerto Rico: A Case Study of Population Control. - Puerto Rico: Political Economy of Population Control in America Latina. Toronto. http://forzadas.pe/ wp-content/uploads/2016/05/Mass_Latin-American-Perspectives-1977.pdf

Nazario T.A. 1961. Nuevas Factes para la Historia de la Puerto Rico. San Juan.

Torres A., Velazquez E. 1998. Puerto Rican Movement. Voices from the Diaspora. Philadelphia: Temple University Press. xvi +381 p.

Vazques Calzanda J.L. 1963. La emigracion puertorriqena: solution o problema? Revista de Ciencias Sociales de la Universidad de Puerto Rico. Vol. XVII. No. 3, Sept.

\section{PUERTO RICO: THE CRISIS OF ETHNIC IDENTITY}

Abstract. The article is devoted to the problems of the formation of the ethnic identity of Puerto Rico, the island state of the Caribbean, which has the status of a freely acceding state to the United States. More than a century of development of relations between Puerto Rico and the USA shows not only the implementation of the policy of American progress making in the global world system, but also how dramatic the desire of a small country to gain its own sovereignty while being in the orbit of US geopolitical interests can be.

Keywords: sovereignty, independence, Puerto Rico, USA, historical and cultural community, ethnic identification, immigration, structural assimilation

\footnotetext{
1 http://resultados2017.ceepur.org/Noche_del_Evento_78/index.html\#es/default/CONSULTA_DESCOLONIZACION_Resumen.xml
} 